\title{
Examining College-Level ELLs' Self-Efficacy Beliefs and Goal Orientation
}

\author{
Hong Shi ${ }^{\mathrm{a}^{*}}$ \\ ${ }^{a}$ China University of Petroleum-Beijing, China \\ *Correspondence: shihong@2005sd@163.com
}

\begin{abstract}
The present study aims to investigate the self-efficacy and goal orientation of college-level English Language Learners (ELLs). It further explored the relationship between self-efficacy and goal orientation. The data were collected from 198 ELLs by using an English Language Learning Survey. Participants had positive self-efficacy toward their English learning. ELLs who were 25 years old and above had a higher level of self-efficacy than those who were less than 25 years old. Females had a greater mastery goal orientation tendency than males. There was a positive correlation between self-efficacy and mastery goals, whereas self-efficacy was negatively correlated with performance-avoidance goals. Teachers are encouraged to provide scaffolding and set assessment focus on ELLs improvement and mastery of content to enhance their self-efficacy and facilitate adopting mastery goals.

Keywords: English language learner, goal orientation, higher education, instructional strategy, selfefficacy
\end{abstract}

\section{INTRODUCTION}

According to the 2020 Open Doors Report on International Educational Exchange, the number of English Language Learners (ELLs) at U.S. colleges and universities surpassed one million during the 2019-20 academic year (Institute of International Education, 2020). Many ELLs have come to the United States from countries where little or no English is spoken. Although many programs or projects in universities are designed to provide regular academic English language courses for international students or scholars, it has been reported that language barriers are identified as the main barriers for ELLs since limited English language proficiency impacts students' self-confidence and participation in academic life. These students may think that they cannot communicate well with L1 users, and this perception affects their communication in class when discussing with others, while asking and answering questions in and outside class (Newman \& Hartman, 2012).

Therefore, many ELLs continue to experience difficulty in developing competency and confidence since they do not acquire English skills quickly enough to achieve academic success (Grafals, 2013). What is more, the increasing number of enrollment of ELLs in post-secondary levels in the U.S. makes it important to consider ELLs' self-efficacy and motivation in their academic life. Researchers in the field of second language learning and teaching found that previous studies were not able to offer effective solutions to improve language learners' motivation, autonomy, and performance because they did not address students' individual learning needs in the classroom, and learners' self-efficacy and goal

Received June 8, 2020; revised September 19, 2020; January 27, 2021; accepted February 8, 2021; electronically published May 1, 2021

Journal of Comparative \& International Higher Education

May, 2021, Vol. 13, No. 2, pp. 65-82.

DOI: $10.32674 /$ jcihe.v13i2.2949

(C) 2021 Journal of Comparative \& International Higher Education. All rights reserved. 
orientation have not yet been integratively examined in an ESL program (Lee \& Zentall, 2012). Furthermore, most of the previous studies explored strategies to help ELLs across levels of prekindergarten to twelfth grade to learn to understand and use English effectively and efficaciously, however, fewer of L2 studies investigate the perspectives of ELLs in the post-secondary setting (BifuhAmbe, 2011).

\section{PURPOSE OF THE STUDY}

To help ELLs in post-secondary levels to achieve English competency and confidence required for academic success is vital for ELLs as well as educators. This study examined self-efficacy beliefs and goal orientation of college-level ELLs enrolled in the ESL program and suggested effective pedagogical practices for higher education faculty, bilingual education specialists, and teacher educators who teach ELLs in university courses. The research questions are as follows:

1. What are the self-efficacy beliefs of college-level ELLs enrolled in the ESL program in relation to their age and sex?

2. What are the goal orientations of college-level ELLs enrolled in the ESL program in relation to their age and sex?

3. What is the relationship between self-efficacy and goal orientation for college-level ELLs enrolled in the ESL program?

\section{THEORETICAL FRAMEWORK}

This study adopts Bandura's views on self-efficacy and Midgley et al.'s views on goal orientation. We will discuss these two theories respectively. Bandura (1977) was first to present, research, and expand on the construct of self-efficacy. According to Bandura's social cognitive theory, learning is knowledge acquisition through cognitive processing of information. The social cognitive theory explains the role of vicarious, self-regulatory, and self-reflective processes in learner development in conjunction with human functioning and also emphasized the importance of cognition in an individual's ability to self-regulate, perform behaviors and complete tasks, it also offers an approach to motivation and self-regulatory development (Bandura, 1997). According to Bandura (1997), a person with higher level of self-efficacy tends to engage in the task, and work harder, for longer portions of time. These behaviors are essential for academic success. Even when failing at a task, the level of self-efficacy plays a role in the learner's cognitive processing of the outcome (Bandura, 1997).

Goal orientation theory includes cognitive, affective, and behavioral components. This theory is highly relevant to explain different academic behaviors, and motivation can be defined by the general goals that students pursue in the process of learning (Midgley et al., 2000). Goal orientation can "reflect a type of standard by which individuals will judge their performance or success, which then has consequences for other motivational beliefs." (Pintrich \& Schunk, 1996, p. 234). Different goals foster different response patterns. The three goals identified by Midgley (2000) are (1) mastery goals, (2) performance-approach goals, (3) performance-avoidance goals. When students have mastery goals, they tend to develop their competence and promote their mastery and understanding (Midgley et al., 2000). Mastery goals focus on acquiring new knowledge or skills and which characterize individuals who enjoy participating in the activity for its own sake. A mastery goal orientation has been associated with adaptive patterns of learning (Elliott \& Dweck, 1988; Midgley et al., 2000). Students who perceive an emphasis on 
mastery goals in the classroom report to persist in the face of difficulty, express intrinsic interests in learning activities, have a more positive attitude toward the class and have a stronger belief that success follows from one's effort (Elliot, 2005; Kaplan \& Maehr, 2007). When students have performanceapproach goals, they aim to demonstrate their competence in an achievement setting. Students try to gain positive external evaluation or favorable judgments or public recognition that they have achieved better than others (Elliot \& Thrash, 2001). A performance-approach orientation has been associated with both adaptive and maladaptive patterns of learning (Midgley et al., 2000). With performance-avoid goals, students are more likely to avoid the demonstration of incompetence in an achievement setting (Midgley et al., 2000). Student's learning interest tends to decrease, and they tend to avoid challenges, withdraw efforts when they encounter difficulty to avoid appearing incapable (Dweck, 1986; Elliott \& Dweck, 1988). Performance-avoidance goal orientation has been associated with maladaptive patterns of learning (Midgley et al., 2000).

\section{LITERATURE REVIEW}

Students' level of motivation, affective states, and actions are strongly influenced by self-efficacy, and when students believe they are capable of performing well on an academic task, they are motivated to perform well (Bandura, 1997). Previous studies identified that academic major, English fluency, learning strategies and career goals were all associated with students' self-efficacy (Lee \& Zentall, 2012). Students' self-efficacy was a key determinant of learning behaviors (Wigfield \& Cambria, 2010). Selfefficacy was a powerful predictor of motivation and performance goals (Komarraju \& Dial, 2014), and test anxiety (Nie, Lau, \& Liau, 2011). These studies either focused on primary or secondary schools exploring grade 9 Singaporean students (e.g., Nie, Lau, \& Liau, 2011) or students' development from childhood and adolescence (e.g., Wigfield \& Cambria, 2010), or emphasized self-efficacy and goals without including demographic factors (e.g., Komarraju \& Dial, 2014). Fewer of them examined postsecondary level ESL students' self-efficacy and goal orientation based on their age and sex.

Some studies found that male students had higher self-efficacy than female students did in science education (Lerdpornkulrat et al. 2012; Stoet \& Geary, 2018). However, some other studies did not find gender differences regarding students' science self-efficacy (e.g., Sezgintürk \& Sungur, 2020). These studies focused on self-efficacy in specific STEM domains. Some studies explored the effectiveness of intervention based on self-efficacy. For example, Namaziandost and Çakmak (2020) found that females had greater improvements in self-efficacy than males in the flipped classroom practice in EFL setting. The relationship between sex and self-efficacy was found complex for university students in multilingual Danish setting under a Bourdieusian perspective (Lueg \& Lueg, 2015). In the field of language learning in ESL context, self-efficacy and sex has not yet been intensively explored from the perspective of cognitive theory.

Researchers who support the cognitive view of motivation believe that goals can give learners directions and momentum toward completing tasks (Pintrich \& Schunk, 2002). Differences in motivational variables for language learning were found between male and female students (Dewaele et al., 2016; Kissau, Kolano, \& Wang 2010). Oga-Baldwin and Nakata (2017) suggested that female students had higher levels of motivation in language learning. Females had higher levels of task orientation and intrinsic motivation than males (Fasczewski, 2012). However, different studies focused on 
different classification of goals, and the present study is based on Midgley's goal orientation theory and classification: (1) mastery goals, (2) performance-approach goals, (3) performance-avoidance goals.

Motivational variables lead to a higher level of self-efficacy (Tin, 2016). Students with higher confidence or positive perceptions in their ability tend to become more mastery-oriented by being involved in challenging tasks and showing positive affect and greater persistence in the face of difficulties. In contrast, students with low confidence or negative self-perceptions are more likely to have performance goal orientation by avoiding challenging tasks and showing low persistence in the face of difficulties (Midgley et al., 2000). For students with mastery goal orientation, learning is inherently interesting, an end in itself (Midgley et al., 2000); thus, students with higher mastery goals are more likely to report better emotional states and enhanced self-efficacy (Kaplan \& Maehr, 2007). It was also reported that students with high-performance goals had a lower level of cognitive engagement and were more likely to present behaviors such as gaining social recognition, pleasing the teacher, or avoiding work (Midgley et al., 2000).

Liem et al. (2008) identified a positive relationship between performance-approach goals and perceived academic efficacy, and suggested that mastery goals and performance-approach goals can generate adaptive behaviors and outcomes. McGregor and Elliot (2002) claimed that approach goals were positive predictors of positive affects such as eagerness, hope, and self-efficacy while avoidance goals were positively related to negative affects such as worry, fear, and anxiety. Deemer, Yough and Morel (2018) found that performance-approach goals were significant positive predictors of procrastination through their relationship with science anxiety only for students with (a) low science self-efficacy and (b) a preference for either low or highly difficult science tasks. These effects were not found for students with high level of efficacy.

The relationship between performance goals and educational behaviors and outcomes is not clearly defined. It was expected that mastery orientation would have the highest positive relation with selfefficacy, followed by a performance-approach orientation. Conversely, it was expected that the performance-avoidance orientation would be negatively correlated with self-efficacy. There is not enough evidence and little in the L2 motivation literature about how L2 learners' goal orientations affect their learning behaviors. Researchers have conducted studies to investigate relationships among self-efficacy beliefs, goal orientation, and performance (Diseth, 2011). However, these relationships have not been examined extensively in the context of L2 learning in U.S. university setting. Koul, Roy, and Lerdpornkulrat (2012) suggested that motivational goal orientations and perceptions of learning and learning environment were gender-dependent and domain-specific.

\section{METHODS}

\section{Participants}

The participants of this study were international students who were taking English courses in the ESL program at a southeastern university in the United States of America. The ESL program include students enrolled in Intensive English Program (IEP) as well as students enrolled in the course INTL1820, Classroom Communication for International Teaching Assistants, and the course INTL 1830, Writing Proficiency in English for International Students. They had to have attended at least one semester in the ESL class. The above criteria were to ensure the ESL participants had identical educational background before they participated in the study. The total number of students who participated in this research was 
207. Among those responses, nine were eliminated because over $15 \%$ of their answers were blank or incomprehensible and that failed us to clearly understand the respondents' views on the questions. Therefore, 198 responses were included in the analysis for this study. Table 1 shows the frequency distribution of 198 survey participants by each demographic group.

Table 1

Demographic Characteristics of Participants

\begin{tabular}{lcc}
\hline Characteristics & f & Percent \\
\hline Sex & & \\
$\quad$ Female & 88 & $44.4 \%$ \\
$\quad$ Male & 110 & $55.6 \%$ \\
Age & & \\
18-24 & 115 & $58.1 \%$ \\
25-59 & 83 & $41.9 \%$ \\
Geographic Background & & \\
$\quad$ African & 4 & $2.0 \%$ \\
Asian & 139 & $70.2 \%$ \\
European & 3 & $1.5 \%$ \\
Middle Eastern & 30 & $15.2 \%$ \\
American (including Brazilian, Colombian, Mexican) & 22 & $11.1 \%$ \\
Years of Study English & & \\
$\quad$ Less than 5 years & 61 & $30.8 \%$ \\
5-10 years & 82 & $41.4 \%$ \\
$\quad$ More than 10 years & 55 & $27.8 \%$ \\
Highest Education Level & & \\
$\quad$ High school & 93 & $47.0 \%$ \\
$\quad$ Bachelor & 67 & $33.8 \%$ \\
$\quad$ Master & 33 & $16.7 \%$ \\
$\quad$ Ph.D. & 5 & $2.5 \%$ \\
Self-Perceptions of Overall English proficiency & & \\
$\quad$ Excellent & 14 & $7.1 \%$ \\
Good & 108 & $54.5 \%$ \\
Fair & 71 & $35.9 \%$ \\
Poor & 5 & $2.5 \%$ \\
\hline
\end{tabular}

Measurements and Procedures

This study included an analysis of data gathered from a self-report questionnaire - an English Language Learning Survey, which was voluntarily completed by ELLs. The survey was adapted from the Motivated Strategies for Learning Questionnaire (MSLQ) (Pintrich, Smith, Garcia, \& McKeachie, 1991), and Patterns of Adaptive Learning Survey (PALS) (Midgley et al., 2000) with some inapplicable items for the context of the study deleted. The MSLQ or the PALS have been used in many previous studies (e.g., Cikrikci-Demirtash, 2005; Duijnhouwera, et al., 2010; Lavasani, et al., 2011; Mendoza-Nápoles, 2020). The MSLQ was developed based on a social-cognitive view of motivation (Pintrich, 2003). The authors of the MSLQ completed two confirmatory factor analyses to determine "the utility of the theoretical model and the operationalization of the MSLQ scales" (Pintrich, Smith, Garcia, \& Mckeachie, 
1993, p. 805). The PALS have been developed and refined over time using goal orientation theory to examine the relation between the learning environment and students' motivation, affect, and behavior. The PALS was first developed based on research showing that a differential emphasis on "mastery" and "performance" goals is associated with adaptive or maladaptive patterns of learning (i.e., Ames, 1992; Dweck, 1986; Maehr, 1984; Midgley et al., 1996). Furthermore, a performance goal orientation can be conceptualized in terms of both approach and avoidance components (i.e., Elliot \& Harackiewicz, 1996; Skaalvik, 1997).

The researcher and the English instructors from the ESL program handed out the survey and collected responses from students. Students' participation in this study was completely anonymous and voluntary. There were no foreseeable risks associated with this study. The participants were asked to honestly answer in terms of how well the statement describes them according to their own English learning experience in the U.S. It was made clear that there was no right or wrong answer for each item. All the participants were informed that all of the personal information, answers, and responses collected from them would be kept confidential.

All collected data were analyzed by using SPSS-PC 20.0. The descriptive analyses were conducted to scrutinize demographic variables and an independent sample t-test was used to investigate students' selfefficacy beliefs and goal orientation concerning age and sex. To answer the question regarding the relationship between self-efficacy, and goal orientation, the Pearson product-moment correlation coefficient was used.

\section{Results}

With the Cronbach Coefficient Alpha test, the results of the tests for self-efficacy, and each type of goal orientation with values higher than .70 showed the evidence of reliability in Table 2.

\section{Table 2}

\section{Reliability of the English Language Learning Survey}

\begin{tabular}{lcc}
\hline & Items & Cronbach's Alpha \\
\hline Self-efficacy & 8 & .903 \\
Goal Orientations & 6 & .833 \\
$\quad$ Mastery & 5 & .883 \\
$\quad$ Performance-approach & 6 & .880 \\
$\quad$ Performance-avoidance & 6 \\
\hline
\end{tabular}

SPSS software was used to perform the descriptive statistics to examine the scores of self-efficacy beliefs. The mean score of self-efficacy is 5.48. The subscale of MSLQ used to measure self-efficacy is a 7-point Likert scale, which indicates that participants in this study have a positive self-efficacy belief. SPSS software was used to perform the independent sample t-test to examine the differences of selfefficacy based on their sex and age. Table 3 shows that the difference in self-efficacy beliefs between male students and female students was not significant. However, as shown in Table 4, students 25 years old and above $(M=5.65)$ had a significantly greater self-efficacy than students less than 25 years old $(\mathrm{M}=5.36), \mathrm{t}(198)=-2.23, \mathrm{p}=.027<.05$. The value of Cohen's $\mathrm{d}$ effect was 0.33 , indicating a moderate effect size. 
Table 3

Summary of Variation in Self-efficacy by Gender

\begin{tabular}{|c|c|c|c|c|c|c|}
\hline \multirow{2}{*}{ Self-efficacy } & \multicolumn{2}{|c|}{$\begin{array}{l}\text { Female } \\
(\mathrm{N}=88)\end{array}$} & \multicolumn{2}{|c|}{$\begin{array}{c}\text { Male } \\
(\mathrm{N}=110)\end{array}$} & \multirow{2}{*}{$t$} & \multirow{2}{*}{$p$} \\
\hline & Mean & $\begin{array}{l}\text { Standard } \\
\text { Deviation }\end{array}$ & Mean & $\begin{array}{l}\text { Standard } \\
\text { Deviation }\end{array}$ & & \\
\hline & 5.58 & .857 & 5.40 & .933 & 1.337 & .183 \\
\hline
\end{tabular}

Table 4

Summary of Variation in Self-efficacy by Age

\begin{tabular}{|c|c|c|c|c|c|c|}
\hline \multirow{2}{*}{ Self-efficacy } & \multicolumn{2}{|c|}{$\begin{array}{l}<25 \\
(\mathrm{~N}=115)\end{array}$} & \multicolumn{2}{|c|}{$\begin{array}{l}\geq 25 \\
(\mathrm{~N}=83)\end{array}$} & \multirow{2}{*}{$t$} & \multirow{2}{*}{$p$} \\
\hline & Mean & $\begin{array}{l}\text { Standard } \\
\text { Deviation }\end{array}$ & Mean & $\begin{array}{l}\text { Standard } \\
\text { Deviation }\end{array}$ & & \\
\hline & 5.36 & .932 & 5.65 & .835 & -2.230 & $.027^{*}$ \\
\hline
\end{tabular}

The independent sample t-test was used to examine the differences in goal orientation based on sex and age. The results of the t-test analyses are illustrated in Table 5. There was only a significant difference in mastery goal orientation between female $(\mathrm{M}=4.01)$ and male students $(\mathrm{M}=3.80), \mathrm{t}(198)$ $=2.087, \mathrm{p}=.038<.05$. The effect size (Cohen's $\mathrm{d}$ effect $=0.30$ ) was moderate. It indicated that female students had a greater tendency to use mastery goals than male students did. No other types of goal orientation produced significant differences based on learners' sex.

A series of t-tests for independent means was run to examine the difference in learners' goal orientations based on their age. The results of the t-test analyses show that there was no significant difference in goal orientation produced based on their age.

Table 5

Summary of Variation in Goal Orientation by Gender

\begin{tabular}{|c|c|c|c|c|c|c|}
\hline \multirow{2}{*}{$\begin{array}{l}\text { Type of Goal } \\
\text { Orientation }\end{array}$} & \multicolumn{2}{|c|}{$\begin{array}{l}\text { Female } \\
(\mathrm{N}=88)\end{array}$} & \multicolumn{2}{|c|}{$\begin{array}{c}\text { Male } \\
(\mathrm{N}=110)\end{array}$} & \multirow{2}{*}{$t$} & \multirow{2}{*}{$p$} \\
\hline & Mean & $\begin{array}{l}\text { Standard } \\
\text { Deviation }\end{array}$ & Mean & $\begin{array}{l}\text { Standard } \\
\text { Deviation }\end{array}$ & & \\
\hline Mastery & 4.01 & .644 & 3.80 & .734 & 2.087 & $.038^{*}$ \\
\hline Performance-approach & 3.38 & .996 & 3.47 & .958 & -.623 & .534 \\
\hline Performance-avoidance & 2.95 & .971 & 3.06 & .931 & -.819 & .414 \\
\hline
\end{tabular}


A Pearson product-moment correlational analysis was conducted to examine if there was any statistically significant relationship between self-efficacy, mastery goals, performance-approach goals, and performance-avoidance goals. The results are illustrated in Table 6. There was a positive correlation between self-efficacy and mastery goals $(\mathrm{r}=.34, \mathrm{p}=.00<.01)$. Whereas self-efficacy was negatively correlated with performance-avoidance goals $(\mathrm{r}=-.19, \mathrm{p}=.005<.01)$. There was no significant relationship between self-efficacy and performance-approach goals.

Table 6

Pearson Product Correlations of Measured Variables

\begin{tabular}{lllll}
\hline Variables & 1 & 2 & 3 & 4 \\
\hline 1.Self-efficacy & -- & $.34^{* *}$ & -.02 & $-.19^{* *}$ \\
2.Mastery Goals & -- & $.23^{* *} .08$ \\
3.Performance-approach Goals & -- & $.51^{* *}$ \\
4.Performance-avoidance Goals & & -- \\
\hline$* p<.05, * * p<.01$
\end{tabular}

\section{DISCUSSIONS}

College-level ELLs enrolled in the ESL program had a positive self-efficacy. The participants had gone through similar English learning situations. In the U.S. University setting, if ELLs' English proficiency does not meet the requirement for taking the regular school classes, they will be required to take English lessons, which are designed for the ESL students. For the college level students, usually the ESL program does the language skills training for these students. Before the students enter the language program, they are tested on their language proficiency. The language program then assigns each student to the proper level of class according to their language ability. Once they complete all the levels of the language program, they are qualified to register in the college or university to take regular classes. Another way the students might skip the language program is to take the TOEFL (Testing of English as a Foreign Language) test. Once their scores on the TOEFL test meet the school requirement, they can register for the regular classes directly. However, if they want to work as teacher assistant or research assistant and their English language proficiency does not meet the requirement they have to take the English courses also. The ESL program is designed for those who are not completely proficient in English and who would like to improve their English skills in a pleasant, academic environment. Thus, participants enrolled in the ESL program had great eagerness or expectation to meet the English course requirement to enter academic programs or work as teacher assistants or research assistants. If they cannot meet the course requirement, they cannot apply for these programs or assistant positions. What is more, it may be the case that the classroom ecology and participation patterns in these students' home countries were different from that in the U.S. For example, in some Asian countries, many ELLs lacked independent learning, initiative, or autonomy in study practices (Fang, 2014; Jingnan, 2011). They were 
more likely to be in teacher-centered classrooms and dependent in student-teacher relations, but when they came to the U.S. classroom setting, and when they were no longer told what to do but had to manage resources, make decisions, and deal with problems, they could develop some characteristics of autonomous learning, and they expect teachers to help them in setting objectives, using learning strategies, and establishing class environment for autonomous learning (Fang \& Zhang, 2012; Fang, 2014). Littlewood (2001) had a similar finding by collecting data from eight Asian and three European countries. Studies have found that ELLs' perceived autonomous support predicts emotional well-being, behaviors or performance (Hall \& Webb, 2014; Sawtelle, Brewe \& Kramer, 2012). Klassen (2004) reviewed 20 articles collected over the course of 25 years to investigate self-efficacy beliefs across cultural groups. The conclusion indicates that self-efficacy beliefs of participants from Asian, collectivist cultures became higher in western, individualist cultures. Students feel successful when they reach goals and this feeling of success increases the students' interest and self-efficacy beliefs in learning (Lipstein \& Renninger, 2007). Thus, participants in the present study were reported as having a positive selfperception, and it indicates that in linguistically diverse classrooms teachers need to establish a relaxing and autonomous class environment to promote students' self-efficacy and self-direction.

The difference in self-efficacy beliefs between male students and female students was not significant. This finding is in accordance with the findings of the study by Sezgintürk and Sungur (2020) and Vogel and Human-Vogel (2016) where the results indicated non-significant gender differences concerning selfefficacy. Nevertheless, it contradicts with the study by Stoet and Geary (2018), which found that male students had higher self-efficacy than female students did in science education. A possible explanation for this finding is that female students were believed behind males in the science education due to social values or the roles imposed upon them (Stoet \& Geary, 2018). However, in the context of language learning, it can counter the bias and stereotypes for females. Furthermore, most students were highly motivated to study English well for its practical functions in their academic communities. As a result, the sex difference in self-efficacy has been minimized.

Participants who were 25 years old and above had a higher level of self-efficacy than those who were less than 25 years old. This could be due to the different program requirements for these students. Most participants who were 25 years old and above had already registered in the university and entered academic programs to pursue their degrees and they just needed to pass the English course exams to apply for teacher assistant or research assistant, however, those who were less than 25 years old needed to meet the college language requirement to register in the university and enter academic programs. As for this group of learners, they were more likely to have a higher level of anxiety and lower level of self-efficacy than those who were 25 years old and above. This finding indicates that teachers should pay more attention to learners were less than 25 years old, and try to establish classroom environment and design class activities to increase their learning interest and intrinsic motivation and decrease their pressure and anxiety.

This study also found that female students had a greater mastery goal orientation tendency than male students. According to Elliot (2005) and Kaplan and Maehr (2007), mastery goals were associated with intrinsic interests and a stronger belief that success follows from one's effort. Based on the finding of the present study, it may be the case that female students anticipated a greater likelihood of success when emphasized on acquiring new skills or mastery of knowledge. Probably, female students tended to focus on acquiring new skills and had better achievements in language learning; however, male students had a 
lower level of motivation, engagement and achievements, and were more likely to seek extrinsic interest or practical goals (e.g. entrance exams and jobs) in language learning (King, 2016).

Self-efficacy was positively correlated with mastery goal orientation. This finding affirmed a previous finding that students with higher self-efficacy or positive perceptions in their ability tended to become more master-oriented (Kaplan \& Maehr, 2007). There are many models of motivation of student learning. According to Midgley's goal orientation theory, a mastery goal orientation has been associated with adaptive patterns of learning (Midgley et al., 2000). Individuals adopting mastery goals tend to be more involved in academic content (Church, et al., 2001) and have a higher level of academic interest (Harackiewicz, et al., 2008). Students who perceive an emphasis on mastery goals are more likely to persist in the face of difficulty, express intrinsic interests, and have a more positive attitude toward class tasks. Pintrich and Schunk (1996) discussed three types of motivational beliefs: (a) self-efficacy beliefs, (b) task value beliefs, and (c) goal orientations. According to Pintrich (2000), goal orientation is related to self-regulated learning, and if students self-regulate their learning, performance, and behavior, they have some goal, standard, or criterion against which to compare their progress. Studies on goal orientation fit nicely with self-regulated learning theory. Pintrich (1999) pointed out that many studies found mastery goals were strongly positively related to self-regulated learning. Self-efficacy is a personal resource that students can draw upon when they are faced with the difficult and time-consuming tasks associated with academic learning and self-regulated learning (Pintrich, 1999). Mastery goals could facilitate intrinsic motivation, and if students are mastery-goal-oriented, they are more likely to be inherently interested in language learning, focus on skill and knowledge development, and have a higher level of emotional states and self-perceptions. It indicates that teachers need to promote ELLs' mastery goals and help learners to set goals to increase cognitive and emotional engagement. It applies to all learners in higher education setting especially for linguistically diverse classrooms in universities.

However, self-efficacy and performance-avoidance goals were negatively correlated, and as performance-avoidance goals increase, the level of self-efficacy decreases. It affirmed a previous finding that students with mastery goal orientation had been found positively correlated with learners' perception, whereas performance-avoidance goal orientation was negatively related to their perception (Utman, 1997). According to Midgley's goal orientation theory, performance-avoidance goal orientation has been associated with maladaptive patterns of learning, and individuals who have performance-avoidance goals, try to avoid the demonstration of incompetence (Midgley et al., 2000). The pressure to avoid negative external evaluation can lead to a cascade of negative affective and behavioral processes. Performanceavoidance goals are almost universally related to negative outcomes (Deemer, Yough, \& Morel, 2018), and especially associated with lower performance expectancies (Smith, 2006) and increased anxiety (Song, et al., 2015). Students with performance-avoidance goals are more likely to have less intrinsic interest or motivation, and present behaviors such as avoiding challenging tasks, withdrawing efforts when they encounter difficulty in order to avoid appearing incapable. This could decrease learners' task involvement and persistence in the face of difficulties. Students may show worries, fears, and anxieties, which perhaps have negative effects on their confidence, self-perceptions, and graded performance. It suggests that teachers design easier tasks for ELLs in classrooms and set evaluation to emphasize their skill or ability development instead of focusing on setting normative performance standard to alleviate learning pressure. Of course, the current findings are only correlational, and further studies are needed to provide more analysis and evidence of causal relations between self-efficacy and goal orientation. 
It was also found that there was no significant relationship between self-efficacy and performanceapproach goals. It is similar to the findings that approach goals have either a negative or no relationship on positive thoughts (McGregor \& Elliot, 2002), feelings (Harackiewicz, Barron, Tauer, \& Elliot, 2002), and behaviors (Wolters, 2003) when a difficulty arises. But it contradicts with the finding of Liem et al. (2008), which identified a positive relationship between performance-approach goals and perceived academic efficacy. The different findings may be due to different participants investigated, and the current study explored college-level ESL students' English language efficacy, whereas Liem's study examined year-9 students' academic efficacy. What is more, participants in this study generally have a positive self-efficacy, and as Deemer, Yough and Morel (2018) identified the effects of performanceapproach goals on behaviors were not found for high efficacy students.

All the findings indicated that among three types of goal orientations, mastery goal orientation was the most adaptive and possessed the facilitating roles in enhancing learners' self-efficacy. It indicates that teachers need to adopt appropriate strategies to facilitate mastery goals and help learners to focus on skill or knowledge development instead of external evaluation or demonstration in linguistically diverse classrooms in universities. It is suggested that classroom practices can be changed to facilitate adaptive efficacy beliefs, encourage interest and value, and foster the adoption of mastery goals (Pintrich \& Schunk, 1996). Based on motivational theories, Perry, Hutchinson, and Thauberger (2007) elaborated the following characteristics of classroom environments: the classroom should provide complex meaningful learning tasks (i.e. tasks that address multiple goals, extend over time, integrate cognitive processes and allow for the creation of a variety of products); learners have opportunities to exercise some degree of control over their learning processes and products; provision of classroom tasks and practices that engage learners in evaluating their work; learners receive instrumental support from peers and teachers, which often takes the form of modeling and scaffolding.

\section{CONCLUSIONS AND IMPLICATIONS}

Conclusions of this quantitative study were that college-level ELLs enrolled in the ESL program had a positive self-efficacy. ELLs who were 25 years old and above had a higher level of self-efficacy than those who were less than 25 years old. Females had a greater mastery goal orientation tendency than males. There was a positive correlation between self-efficacy and mastery goals, whereas self-efficacy was negatively correlated with performance-avoidance goals.

The findings are of relevance to bilingual education specialists, higher education faculty, and teacher educators who teach ELLs in university courses and is very timely, given the current institutional push to recruit more ELLs to college campuses. It is suggested that English language educators in linguistically diverse classrooms assist in promoting higher education level ELLs' confidence, motivation and learner autonomy. Cummins (2001) identified three fundamental pillars of effective language instruction for ESL students-activate prior knowledge/build background knowledge, access content, and extend the language. Teachers can use strategies to influence self-efficacy by making the task appear easier so that students believe they are capable of completing the task. By applying prior knowledge to the new content and extending learners' knowledge, learners can know not only what to think and do, but how to think and do and new skills can be applied in new contexts. It is suggested that teachers make complex English language accessible to language learners; create settings to involve learners in the activities and facilitate the mastery of the English academic course content; include visual support, hands-on activities, and 
timely feedback in curriculum design and classroom activities. In order to increase the sense of selfsatisfaction and motivation, it is better to design meaningful classroom activities to encourage learners to persist longer in the learning tasks and involve students' actively in classroom tasks.

ELLs can be encouraged to adopt mastery goals and teachers are suggested to design class tasks and activities that emphasize the individual's interest, ability and skill development. Teachers need to support and guide learners by providing feedback, encouragement and reinforcement. Learners also need to learn skills to deal with stress and other negative affective factors that may interfere with learning and reduce learners' self-efficacy. It is suggested that learners become self-motivated and self-disciplined, thus promoting self-efficacy, which in turn facilitates goal orientation and performance of learners.

Teachers are encouraged to adopt evaluation methods to focus on ELLs' ability improvement and mastery of academic content. Participative and interactive assessment methods like self or peerassessment can be used to evaluate ELLs performance to help them feel more confident, efficacious, and in control of their learning.

This study explored one university campus whose programs may not precisely parallel others. Students' behaviors and perceptions cannot be understood by only using a self-reporting questionnaire. Further research can be done with a large number of participants to examine factors that influence ELLs' self-efficacy and goal orientation. Studies can be carried out to provide more analysis of causal relations between self-efficacy and goal orientation. Other methods such as observation, focus group, and diaries can be used to explore how to foster ELLs' self-efficacy and adoption of mastery goals. Other institutional organizations' perspectives can be investigated together with students' perspectives to help understand students' behaviors in campus. Qualitative studies can be combined with quantitative studies to explore further learners' individual differences, motivational variables and their relations with proficiency in an ESL setting.

\section{ACKNOWLEDGEMENT}

This work was supported by Science Foundation of China University of Petroleum, Beijing (No. ZX20170005) and Beijing Outstanding Talent Training Foundation (No. 69J19009).

Hong Shi, PhD of Adult Education, teaches at the School of Foreign Languages at China University of Petroleum-Beijing. Her research interests include English language learners' self-efficacy, learning strategies, self-directed language learning, and goal orientation. She has published 16 peer-reviewed journal articles, and 1 book chapter. Her work is supported by Science Foundation of China University of Petroleum-Beijing [number ZX20170005] and Beijing Outstanding Talent Training Foundation [number 69J19009]. Email: shihong2005sd@163.com or hzs0032@auburn.edu.

\section{REFERENCES}

Ames, C. (1992). Classrooms: Goals, structures, and student motivation. Journal of Educational Psychology, 84(3), 261-271.

Bandura, A. (2006). Guide for constructing self-efficacy scales. In F. Pajares \& T. Urdan (Eds), Self-efficacy and Adolescence (pp. 307-337). Information Age Publishing.

Bandura, A. (1997). Self-efficacy: The exercise of control. Worth Publishers.

Bandura, A. (1977). Social learning theory. Prentice Hall. 
Bifuh-Ambe, E. (2011). Post-secondary learning: Recognizing the needs of English language learners in mainstream university classrooms. Multicultural Education, 18(3), 13-19.

Church, M. A., Elliot, A. J., \& Gable, S. L. (2001). Perceptions of classroom environment, achievement goals, and achievement outcomes. Journal of Educational Psychology, 93, 43-54. doi:10.1037//0022-0063.93.1.43.

Cikrikci-Demirtash, R. N. (2005). Adaptation of the patterns of adaptive learning scales (PALS) to Turkish students: Factorial validity and reliability. International Journal of Educational Reform, 14(2), 173-191.

Cummins, J. (2001). Negotiating identities: Education for empowerment in a diverse society (2nd ed.). California Association for Bilingual Education.

Deemer E. D., Yough, M., Morel, S. A. (2018). Performance-approach goals, science task preference, and academic procrastination: Exploring the moderating role of competence perceptions. Motivation \& Emotion, 42(2), 200213. doi:10.1007/s11031-017-9649-z.

Dewaele, J.-M., MacIntyre, P. D., Boudreau, C., \& Dewaele, L. (2016). Do girls have all the fun? Anxiety and enjoyment in the foreign language classroom. Theory and Practice of Second Language Acquisition, 2, 41-63.

Diseth, A. (2011). Self-efficacy, goal orientation and learning strategies as mediators between preceding and subsequent academic achievement. Learning and Individual Differences, 21(2), 191-195. doi:10.1016/j.lindif.2011.01.003

Duijnhouwera, H., Prinsa, J. F., \& Stokkinga, K. M. (2010). Progress feedback effects on students' writing mastery goal, self-efficacy beliefs, and performance. Educational Research \& Evaluation, 16(1), 53-74.

Dweck, C. S. (1986). Motivational processes affecting learning. American Psychologist, 41(10), 1040-1048. doi:10.1037/0003-066X.41.10.1040

Elliot, A. J. (2005). A conceptual history of the achievement goal construct. In A. J. Elliot \& C. S. Dweck (Eds.), Handbook of Competence and Motivation (pp. 52-72). Guilford Press.

Elliot, A. J., \& Harackiewicz, J. M. (1996). Approach and avoidance achievement goals and intrinsic motivation: A mediational analysis. Journal of Personality \& Social Psychology, 70(3), 461-475.

Elliot, A. J., \& Thrash, T. M. (2001). Achievement goals and the hierarchical model of achievement motivation. Educational Psychology Review, 13, 139-156.

Elliott, E. S., \& Dweck, C. S. (1988). Goals: An approach to motivation and achievement. Journal of Personality and Social Psychology, 54, 5-12. doi:10.1037/0022-3514.54.1.5

Fang, F. M., \& Zhang, L. (2012). Teachers' roles in promoting students' learner autonomy in China. English Language Teaching, 5(4), 51-56.

Fang, Z. (2014). A discussion about college teachers' roles in English viewing, listening and speaking autonomous learning. International Forum of Teaching and Studies, 10(1), 50-55.

Fasczewski, K. S. (2012). So you are having a bad day: Gender, goal orientation and in-competition attrition rate in competitive cyclists. Dissertations \& Theses-Gradworks.

Grafals, Z. (2013). English learning predictors of listening and speaking self-efficacy for adult second language learners [doctoral dissertation]. Retrieved from ProQuest. (UMI 3572507).

Hall, N., \& Webb, D. (2014). Instructors' support of student autonomy in an introductory physics course. Physical Review Special Topics-Physics Education Research, 10, 1-22.

Harackiewicz, J. M., Barron, K. E., Tauer, J. M., \& Elliot, A. J. (2002). Predicting success in college: A longitudinal study of achievement goals and ability measures as predictors of interest and performance from freshman year through graduation. Journal of Educational Psychology, 94(3), 562-575. doi:10.1037/0022-0663.94.3.562

Harackiewicz, J. M., Durik, A. M., Barron, K. E., Linnenbrink- Garcia, L., \& Tauer, J. M. (2008). The role of achievement goals in the development of interest: Reciprocal relations between achievement goals, interest, and performance. Journal of Educational Psychology, 100, 105-122. doi:10.1037/0022-0663.100.1.105.

Jingnan, S. (2011). Autonomy in EFL education. Canadian Social Science, 7(5), 27-32.

Kaplan, A., \& Maehr. M. L. (2007). The contribution and prospects of goal orientation theory. Educational Psychology Review, 19, 141-184. doi:10.1007/s10648-006-9012-5 
King, R. B. (2016). Gender differences in motivation, engagement and achievement are related to students' perceptions of peers-but not of parent or teacher-attitudes toward school. Learning and Individual Differences, $52,60-71$.

Kissau, S., Kolano, L., \& Wang, C. (2010). Perceptions of gender differences in high school students' motivation to learn Spanish. Foreign Language Annals, 43, 703-721.

Klassen, R. M. (2004). A cross-cultural investigation of the efficacy beliefs of South Asian immigrant and Anglo Canadian nonimmigrant early adolescents. Journal of Educational Psychology, 96(4), 731-742. http://dx.doi.org/10.1037/0022-0663.96.4.731

Komarraju, M., \& Dial, C. (2014). Academic identity, self-efficacy, and self-esteem predict self-determined motivation and goals. Learning and Individual Differences, 32, 1-8.

Koul, R., Roy, L., \& Lerdpornkulrat, T. (2012). Motivational goal orientation, perceptions of biology and physics classroom learning environments, and gender. Learning Environments Research, 15(2), 217-229.

Lavasani, M. G., Mirhosseini, F. S., Hejazi, E., \& Davoodi, M. (2011). The effect of self-regulation learning strategies training on the academic motivation and self-efficacy. Procedia - Social and Behavioral Sciences, 29(1), 627-632.

Lee, J., \& Zentall, S. S. (2012). Reading motivational differences among groups: Reading disability (RD), attention deficit hyperactivity disorder (ADHD), $\mathrm{RD}+\mathrm{ADHD}$, and typical comparison. Learning and Individual Differences, 22(6), 778-785. doi:10.1016/j.lindif.2012.05.010.

Lerdpornkulrat, T., Koul, R., \& Sujivorakul, C. (2012). The influence of ability beliefs and motivational orientation on the self-efficacy of high school students in Thailand. Australian Journal of Education, 56(2), 163-181.

Liem, A. D., Lau, S., \& Nie, Y. (2008). The role of self-efficacy, task value, and achievement goals in predicting learning strategies, task disengagement, peer relationship, and achievement outcome. Contemporary Educational Psychology, 33(4), 486-512. doi:10.1016/j.cedpsych.2007.08.001

Lipstein, R. L., \& Renninger, K. A. (2007). "Putting things into words": The development of 12-15-year-old students' interest for writing. In S. Hidi \& P. Boscolo (Eds.), Motivation to Write (pp. 113-140). Kluwer. doi: 10.1163/9781849508216_008

Littlewood, W. (2001). Students' attitudes to classroom English learning: A cross-cultural study. Language Teaching Research, 5(1), 3-28.

Lueg, K., \& Lueg, R. (2015). Why do students choose English as a medium of instruction? A Bourdieusian perspective on the study strategies of non-native English speakers. Academy of Management Learning \& Education, 14, 5-30.

Maehr, M. L. (1984). Meaning and motivation: Toward a theory of personal investment. In R. Ames \& C. Ames (Eds.), Research on Motivation in Education: Student Motivation (pp.115-144). Academic Press.

McGregor, H. A., \& Elliot, A. J. (2002). Achievement goals as predictors of achievement-relevant processes prior to task engagement. Journal of Educational Psychology, 94(2), 381-395. doi:10.1037/0022-0663.94.2.381

Mendoza-Nápoles, C. A. (2020). Validation of learning adaptation patterns (PALS) scales in elementary Mexican school students. Current Psychology, 1-11.

Midgley, C., Maehr, M. L., Hicks, L., Roeser, R., Urdan, T., Anderman, E., \& Kaplan, A. (1996). The Patterns of Adaptive Learning Survey (PALS). The University of Michigan.

Midgley, C., Maehr, M. L., Hruda, L. Z., Anderman, E., Anderman, L., Gheen, K. E., \& Urdan, T. (2000). Manual for the patterns of adaptive learning scales. University of Michigan.

Namaziandost, E., \& Çakmak, F. (2020). An account of EFL learners' self-efficacy and gender in the Flipped Classroom Model. Education and Information Technologies. https://doi.org/10.1007/s10639-020-10167-7

Newman, B. J., \& Hartman, T. K. (2012). Foreign language exposure, cultural threat, and opposition to immigration. Political Psychology, 33(5), 635-657. doi:10.1111/j.1467-9221.2012.00904.x

Nie, Y., Lau, S., \& Liau, A. K. (2011). Role of academic self-efficacy in moderating the relation between task 
importance and test anxiety. Learning and Individual Differences, 21, 736-741.

Oga-Baldwin, W. L. Q., \& Nakata, Y. (2017). Engagement, gender, and motivation: A predictive model for Japanese young language learners. System, 65, 151-163.

Perry, N. E., Hutchinson, L., \& Thauberger, C. (2007). Mentoring student teachers to design and implement literacy tasks that support self-regulated learning and writing. Reading and Writing Quarterly, 23, 27-50. doi:10.1080/10573560600837636.

Pintrich, P. R. (2003). A motivational science perspective on the role of student motivation in learning and teaching contexts. Journal of Educational Psychology, 95(4), 667-686.

Pintrich, P. R. (2000). The role of goal orientation in self-regulated learning. In M. Boekaerts, P. R. Pintrich, \& M. Zeidner, Handbook of Self-regulation (pp. 451-529). Academic Press.

Pintrich, P. R. (1999). The role of motivation in promoting and sustaining self-regulated learning. International Journal of Educational Research, 31, 459-470.

Pintrich, P. R., \& Schunk, D. H. (2002). Motivation in education: Theory, research, and applications (2nd ed.). Merrill-Prentice Hall.

Pintrich, P. R., \& Schunk, D. H. (1996). Motivation in education: Theory, research, and applications. Prentice Hall Merrill.

Pintrich, P. R., Smith, D. A., Garcia, T., \& Mckeachie, W. J. (1993). Reliability and predictive validity of the motivated strategies for learning questionnaire (MSLQ). Educational and Psychological Measurement, 53, 801813. doi: 10.1177/0013164493053003024

Pintrich, P. R., Smith, D. A., Garcia, T., \& Mckeachie, W. J. (1991). A manual for the use of the motivated strategies for learning questionnaire (MSLQ). Retrieved from ERIC database. (ED338122).

Sawtelle, V., Brewe, E., \& Kramer, L. H. (2012). Exploring the relationship between self-efficacy and retention in introductory physics. Journal of Research in Science Teaching, 49, 1096-1121.

Sezgintürk, M., \& Sungur, S. (2020). A multidimensional investigation of students' science self-efficacy: The role of gender. Illkogretim Online-Elementary Education Online, 19(1), 208-218.

Skaalvik, E. (1997). Self-enhancing and self-defeating ego orientation: Relations with task avoidance orientation, achievement, self-perception, and anxiety. Journal of Educational Psychology, 89, 71-81.

Smith, J. L. (2006). The interplay among stereotypes, performance-avoidance goals, and women's math performance expectations. Sex Roles, 54, 287-296. doi:10.1007/s11199-006-9345-z.

Song, J., Bong, M., Lee, K., \& Kim, S. (2015). Longitudinal investigation into the role of perceived social support in adolescents' academic motivation and achievement. Journal of Educational Psychology, 107, 821-841. doi:10.1037/edu0000016.

Stoet, G., \& Geary, D. C. (2018). The gender-equality paradox in science, technology, engineering, and mathematics education. Psychological Science, 29(4), 581-593.

Tin, T. B. (2016). Stimulating student interest in language learning: Theory, research and practice. Palgrave Macmillan.

Utman, C. H. (1997). Performance effects of motivational states: A meta-analysis. Personality and Social Psychology Review, 1(2), 170-182. doi:10.1207/s15327957pspr0102_4

Vogel, F. R., \& Human-Vogel, S. (2016). Academic commitment and self-efficacy as predictors of academic achievement in additional materials science. Higher Education Research \& Development, 35(6), 1298-1310.

Wigfield, A., \& Cambria, J. (2010). Students' achievement values, goal orientations, and interest: Definitions, development, and relations to achievement outcomes. Developmental Review, 30, 1-35.

Wolters, C. A. (2003). Understanding procrastination from a self-regulated learning perspective. Journal of Educational Psychology, 95(1), 179-87. doi:10.1037/0022-0663.95.1.179 


\section{APPENDIX}

\section{English Language Learning Survey}

The following questions ask about your self-efficacy, language learning strategy use and goal orientation about English language learning. Answer in terms of how well the statement describes you. This usually takes about 10 minutes to complete. If you have any questions, let the researcher know immediately.

\section{Demographic Information}

Please first answer the following questions about yourself. Your answers will be treated in a confidential manner and only identified to the researcher for this study.

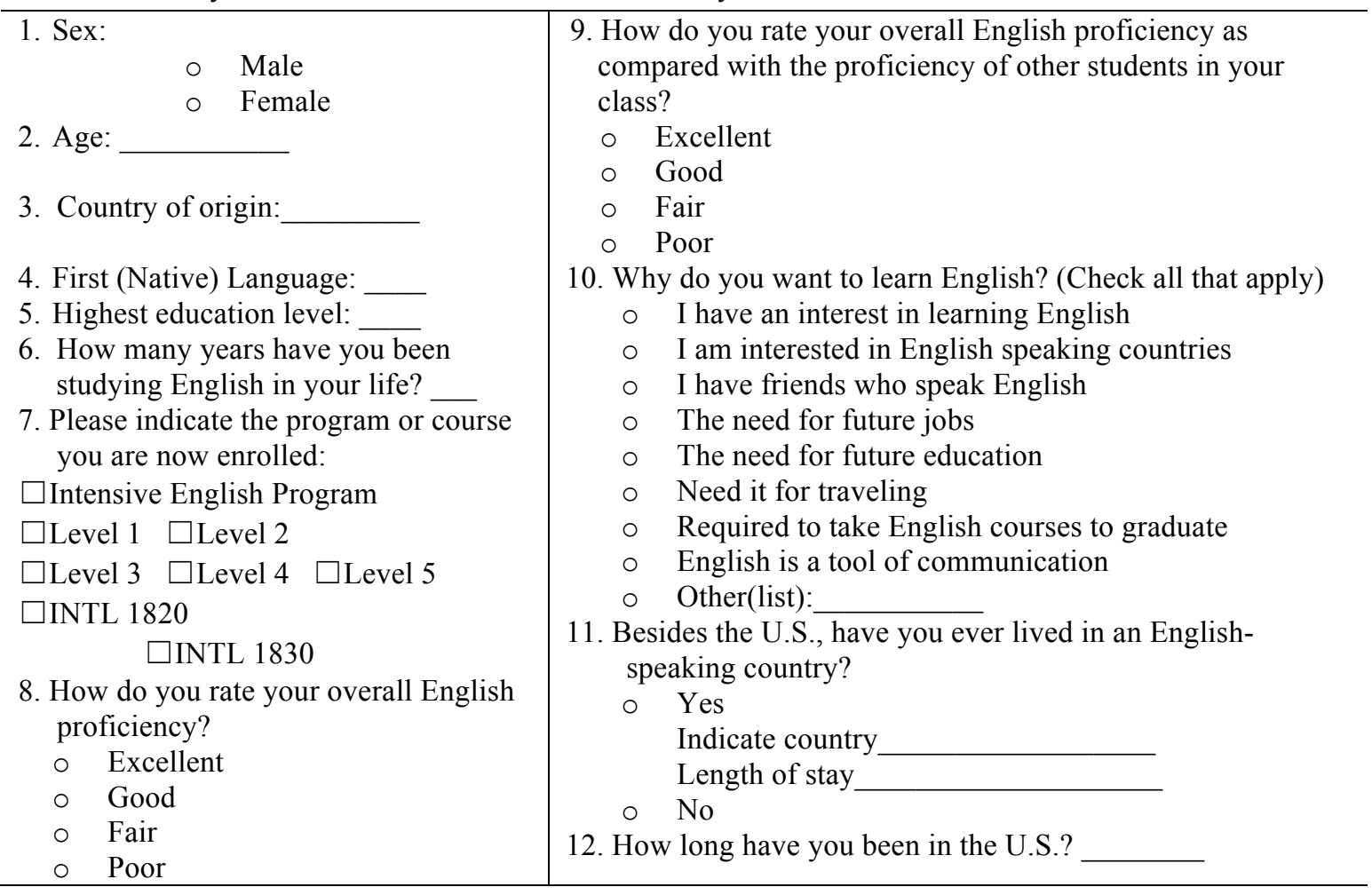

\section{Part A-Self-Efficacy}

Please read each statement and check the box that best describes how you feel: $1=$ Not at all true of me to $7=$ Very true of me

\begin{tabular}{|c|c|c|c|c|c|c|c|}
\hline & $\begin{array}{c}\text { Not at } \\
\text { all } \\
\text { true of } \\
\text { me } \\
1 \\
\end{array}$ & 2 & 3 & 4 & 5 & 6 & $\begin{array}{c}\text { Very } \\
\text { true of } \\
\text { me } \\
\\
7\end{array}$ \\
\hline 1. I believe I will receive an excellent grade in this English class. & & & & & & & \\
\hline $\begin{array}{l}\text { 2. I'm certain I can understand the most difficult material presented } \\
\text { in the readings for this English class. }\end{array}$ & & & & & & & \\
\hline $\begin{array}{l}\text { 3. I'm confident I can understand the basic concepts taught in this } \\
\text { English course. }\end{array}$ & & & & & & & \\
\hline $\begin{array}{l}\text { 4. I'm confident I can understand the most complex material } \\
\text { presented by the instructor in this English course. }\end{array}$ & & & & & & & \\
\hline 5. I'm confident I can do an excellent job on the assignments and & & & & & & & \\
\hline
\end{tabular}


tests in this English course.

6. I expect to do well in this English class.

7. I'm certain I can master the skills being taught in this English class.

8. Considering the difficulty of this English course, the teacher, and my skills, I think I will do well in this class.

Part B-Goal Orientation

Please read each statement and check the box that best describes how you feel:

$1=$ Never or almost never true of me to $5=$ Always or almost always true of me

\begin{tabular}{|c|c|c|c|c|c|}
\hline & $\begin{array}{c}\text { Never or } \\
\text { almost never } \\
\text { true of me } \\
1 \\
1\end{array}$ & $\begin{array}{c}\text { Usually } \\
\text { not true of } \\
\text { me } \\
\\
2 \\
\end{array}$ & $\begin{array}{c}\text { Some- } \\
\text { what true } \\
\text { of me } \\
\\
3 \\
\end{array}$ & $\begin{array}{c}\text { Usually } \\
\text { true of } \\
\text { me }\end{array}$ & $\begin{array}{c}\text { Always or } \\
\text { almost } \\
\text { always true } \\
\text { of me } \\
5 \\
\end{array}$ \\
\hline $\begin{array}{l}\text { 9. I like class work that I'll learn from } \\
\text { even if I make a lot of mistakes. }\end{array}$ & & & & & \\
\hline $\begin{array}{l}\text { 10. An important reason why I do my } \\
\text { class work in this English class is } \\
\text { because I like to learn new things. }\end{array}$ & & & & & \\
\hline $\begin{array}{l}\text { 11. I like class work in this English } \\
\text { class best when it really makes me } \\
\text { think. }\end{array}$ & & & & & \\
\hline $\begin{array}{l}\text { 12. An important reason why I do my } \\
\text { work in this English class is because I } \\
\text { want to get better at it. }\end{array}$ & & & & & \\
\hline $\begin{array}{l}\text { 13. An important reason I do my class } \\
\text { work is because I enjoy it. }\end{array}$ & & & & & \\
\hline $\begin{array}{l}\text { 14. I do my class work in this English } \\
\text { class because I'm interested in it. }\end{array}$ & & & & & \\
\hline $\begin{array}{l}\text { 15. I would feel really good if I were the } \\
\text { only one who could answer the } \\
\text { teacher's questions in class. }\end{array}$ & & & & & \\
\hline $\begin{array}{l}\text { 16. I want to do better than other } \\
\text { students in my English class. }\end{array}$ & & & & & \\
\hline $\begin{array}{l}\text { 17. I would feel successful in class if I } \\
\text { did better than most of the other } \\
\text { students in this English class. }\end{array}$ & & & & & \\
\hline $\begin{array}{l}\text { 18. I'd like to show my teacher that I'm } \\
\text { smarter than the other students in this } \\
\text { English class. }\end{array}$ & & & & & \\
\hline $\begin{array}{l}\text { 19. Doing better than other students in } \\
\text { English class is important to me. }\end{array}$ & & & & & \\
\hline $\begin{array}{l}\text { 20. It's very important to me that I } \\
\text { don't look stupid in my English class. }\end{array}$ & & & & & \\
\hline $\begin{array}{l}\text { 21. An important reason I do my class } \\
\text { work is so that I don't embarrass } \\
\text { myself. }\end{array}$ & & & & & \\
\hline $\begin{array}{l}\text { 22. The reason I do my class work is so } \\
\text { my teacher doesn't think I know less } \\
\text { than others in this English class. }\end{array}$ & & & & & \\
\hline $\begin{array}{l}\text { 23. The reason I do my work is so } \\
\text { others won't think I'm dumb. }\end{array}$ & & & & & \\
\hline
\end{tabular}




\begin{tabular}{l|c|c|c|c|c}
\hline & $\begin{array}{c}\text { Never or } \\
\text { almost never } \\
\text { true of me }\end{array}$ & $\begin{array}{c}\text { Usually } \\
\text { not true of } \\
\text { me }\end{array}$ & $\begin{array}{c}\text { Some- } \\
\text { what true } \\
\text { of me }\end{array}$ & $\begin{array}{c}\text { Usually } \\
\text { true of } \\
\text { me }\end{array}$ & $\begin{array}{c}\text { Always or } \\
\text { almost } \\
\text { always true } \\
\text { of me }\end{array}$ \\
\hline $\begin{array}{l}\text { 24. One of my main goals in this } \\
\text { English class is to avoid looking like I } \\
\text { can't do my work. }\end{array}$ & 1 & 2 & 3 & 4 & 5 \\
\hline $\begin{array}{l}\text { 25. One reason I would not participate } \\
\text { in this English class is to avoid looking } \\
\text { stupid. }\end{array}$ & & & & & \\
\hline
\end{tabular}

Survey adapted from the Motivated Strategies for Learning Questionnaire (MSLQ) (Pintrich, Smith, Garcia, \& McKeachie, 1993), and the Patterns of Adaptive Learning Strategies (PALS) survey (Midgley et al., 2000). 